\title{
Umbellula pomona sp. nov., a new sea pen from Mar del Plata Submarine Canyon (Cnidaria: Octocorallia: Pennatulacea)
}

\author{
Jessica RISARO ${ }^{1}$, Gary C. WILLIAMS ${ }^{2}$, Daniela PEREYRA ${ }^{3} \&$ Daniel LAURETTA $^{4}$ \\ ${ }^{1,3,4}$ Museo Argentino de Ciencias Naturales "Bernardino Rivadavia" - CONICET, \\ Av. Ángel Gallardo 470, Buenos Aires, Argentina. \\ ${ }^{2}$ Department of Invertebrate Zoology and Geology, California Academy of Sciences, \\ Golden Gate Park, San Francisco, California 94118, USA. \\ ${ }^{*}$ Corresponding author: jessicarisaro@gmail.com \\ 2Email: gwilliams@calacademy.org \\ ${ }^{3}$ Email: mdr.pereyra@gmail.com \\ ㄹmail:dlauretta@gmail.com

\footnotetext{
${ }^{1}$ urn:1sid:zoobank.org:author:7FC3A3C5-D9D1-443E-AD57-D11493E4B8B7

${ }^{2}$ urn:1sid:zoobank.org:author:2C3F7EA8-C963-4514-B299-E2867CA85C98

${ }^{3}$ urn:1sid:zoobank.org:author:F96E16B1-548B-4430-B94A-1495A7C1749F

${ }^{4}$ urn:1sid:zoobank.org:author:1E61C098-4037-4002-A4DA-C2118339163E
}

\begin{abstract}
Sea pens (Cnidaria: Anthozoa: Pennatulacea) constitute a distinctive group of colonial marine invertebrates. They inhabit the world's oceans, from shallow to deep waters. Studies about this group in Argentina are scarce, and no species have been described in the area in over a decade. Based on samples collected in Mar del Plata Submarine Canyon at about $3000 \mathrm{~m}$ deep we describe a new species of sea pen, Umbellula pomona Risaro, Williams \& Lauretta sp. nov. This is a spiculate Umbellula that differs from other species of Umbellula with sclerites, by the number, development and distribution of the autozooids in its terminal cluster, as well as the shape of its axis. Molecular data also distinguishes it from other known species. Of the forty-three described species approximately ten are considered valid for the genus Umbellula, four of them are registered for the South Atlantic Ocean and only three are described for the Antarctic region. Since sampling efforts in this area have been scarce, the number of species of sea pens from the region is likely to increase substantially in the coming years.
\end{abstract}

Keywords. Argentina, benthos, octocorals, taxonomy, biodiversity.

Risaro J., Williams G.C., Pereyra D. \& Lauretta D. 2020. Umbellula pomona sp. nov., a new sea pen from Mar del Plata Submarine Canyon (Cnidaria: Octocorallia: Pennatulacea). European Journal of Taxonomy 720: 121-143. https://doi.org/10.5852/ejt.2020.720.1121

\section{Introduction}

Pennatulaceans, known as sea pens, are a distinctive group of octocorals, in the order Pennatulacea Verrill, 1864 (Cnidaria, Anthozoa). They are formed from a single large primary polyp with (usually) 
lateral buddings of the body wall that give rise to all secondary zooids that comprise the colony. Sea pens are almost exclusively adapted for soft substrata (Williams 1992) with a few exceptions (Williams \& Alderslade 2011). Hitherto, of the approximately 450 described species, at least 200 are estimated to be valid (Williams 1995), grouped in thirty-seven genera and fourteen families of living pennatulaceans (Williams 2011, 2015; García-Cárdenas et al. 2019). Despite the fact that only a few works deal with the phylogenetic relationships of the group, recent data using mitochondrial genes (mtMutS and ND2) confirmed the Pennatulacea as a monophyletic group (McFadden et al. 2006; Dolan et al. 2013; Kushida \& Reimer 2019).

Only a few taxonomic works dealing with sea pens from the southwestern Atlantic Ocean (SAO) (from the area of Argentina) have been made so far (Kölliker 1880; Acuña \& Zamponi 1992; Zamponi \& Pérez 1995; Pérez \& Zamponi 2004; Williams 2011). This is the first description of a new species for the area in fifteen years because of the low number of studies made in this region, so we estimate that while more expeditions can be made, the biodiversity of this group will increase considerably and nowadays its biodiversity is likely to be underestimated. Umbellula Cuvier, 1798 is the only genus described within the family Umbellulidae Lindahl, 1874. It is characterized by an elongate and slender rachis with autozooids restricted to the distal region of the colony, usually forming a dense umbellate cluster. Siphonozooids are present at the base of the autozooids or on bare parts of the rachis. Most of the species lack sclerites, but when present, they are rods, spindles or needles, three-flanged, and usually round in cross-section (Williams 1990).

The Mar del Plata Submarine Canyon is located at the continental margin of Argentina at about $38^{\circ} \mathrm{S}$ latitude. The geomorphology of the external shelf and the submarine canyon of the Argentinian continental margin are strongly influenced by the Malvinas Current, a branch of the Antarctic Circumpolar Current that runs towards the northeastern region of the Argentinian continental margin (Piola \& Matano 2001). The Malvinas Current transports cold subantarctic water and collides with the Brazil Current that carries warm waters along the continental slope of South America. This collision generates one of the most energetic regions of the world ocean (Piola \& Matano 2001).

Although submarine canyons are known to be hotspots of benthic biomass and are globally numerous, these environments are very poorly sampled (Del Río Iglesias et al. 2012), therefore it is very important to study their biodiversity. Based on the specimens collected during the expeditions to the canyon (2012 and 2013), several new records and new species of Cnidaria Verrill, 1865, Mollusca Linnaeus, 1758 and Echinodermata Bruguière, 1791 have already been published (Cerino \& Lauretta 2013; Martinez et al. 2014; Farías et al. 2015; Signorelli \& Pastorino 2015; Maggioni et al. 2016; Pastorino \& Sánchez 2016; Pastorino 2016, 2019; Martinez \& Penchaszadeh 2017; Pereira \& Doti 2017; Bernal et al. 2018). Here, we describe a new species of Umbellula from Mar del Plata Submarine Canyon based on specimens collected between $2934 \mathrm{~m}$ and $3282 \mathrm{~m}$ deep, using both morphological and molecular data.

\section{Material and methods}

\section{Taxonomic data}

During the "Talud Continental III" expedition to Mar del Plata Submarine Canyon in September 2013, four specimens of Umbellula pomona Risaro, Williams \& Lauretta sp. nov. were collected at stations $\mathrm{N}^{\circ} 45$ (38 $1.913^{\prime} \mathrm{S}, 53^{\circ} 39.268^{\prime} \mathrm{W}, 2934 \mathrm{~m}$ depth) and $\mathrm{N}^{\circ} 46$ (38 $5.310^{\prime} \mathrm{S}, 53^{\circ} 39.988^{\prime} \mathrm{W}, 3282 \mathrm{~m}$ depth) (Fig. 1) using trawls and preserved in ethanol 96\%. All the studied specimens were deposited in the Argentinian Museum of Natural Sciences "Bernardino Rivadavia" (Museo Argentino de Ciencias Naturales "Bernardino Rivadavia"- MACN), Buenos Aires, Argentina.

The general morphology of the specimens, the distribution of sclerites and the shape of transverse sections of the axis were studied by the naked eye and using a stereoscopic microscope. For the sclerites' shape 
we followed the nomenclature of Bayer et al. (1983). Scanning electron microscopy (SEM) was used to examine the shape and length of the sclerites from the tentacles, polyp body and rachis of the colonies and the shape of the axis in transverse section. All measures of the peduncle (when possible), rachis, polyp's body and tentacles were done with a digital caliper and correspond to the holotype. Photographs of the colonies were taken using a digital SLR Nikon D800 camera with a Nikkor $60 \mathrm{~mm}$ F2.8 macro lens. To separate and prepare the sclerites of rachis, polyp's body and tentacles to examine them by SEM, a portion of each tissue was cut and treated with diluted sodium hypochlorite (commercial bleach) for fifteen minutes and then washed with distilled water. Finally, the residual of water was evaporated with ethanol $96 \%$ and the sclerites were placed on SEM tubs; for the axis sections, a portion of it was cut and all soft tissue was retired, then the same protocol of the sclerites was followed.

\section{Molecular data}

Small tissue fragments were obtained from the holotype of Umbellula pomona sp. nov. and one paratype, both preserved in $96 \%$ ethanol. The samples were preliminarily washed with deionized water, allowing removal of ethanol. Total genomic DNA was extracted following the salting-out method (Miller et al. 1988). Following previous published works (Dolan et al. 2013; Kushida \& Reimer 2019) we amplified two mitochondrial regions: mtMuts (France \& Hoover 2002; Sánchez et al. 2003) and ND2 (McFadden et al. 2004). The primer's sequences and thermocycling profiles used to amplify each target gene are described in Table S1 (Supplementary File 1).

Amplifications were carried out in $20 \mu$ reaction mixtures containing $1 \times$ PCR buffer mix (the buffer includes dNTPs and $\mathrm{MgCl}_{2}$ ), $0.2 \mu \mathrm{M}$ of each primer, $1 \mathrm{U}$ of Taq polymerase (MyTaq DNA Polymerase, Bioline), $4 \mu \mathrm{g}$ of Bovine Serum Albumin (BSA), $2 \mu$ l containing $<10 \mathrm{ng}$ template DNA, and brought to final volume with $\mathrm{dH}_{2} \mathrm{O}$. The PCR reactions were performed in a T100TM thermocycler (Bio-Rad, USA), with negative controls included to verify the absence of contamination. The PCR products size was

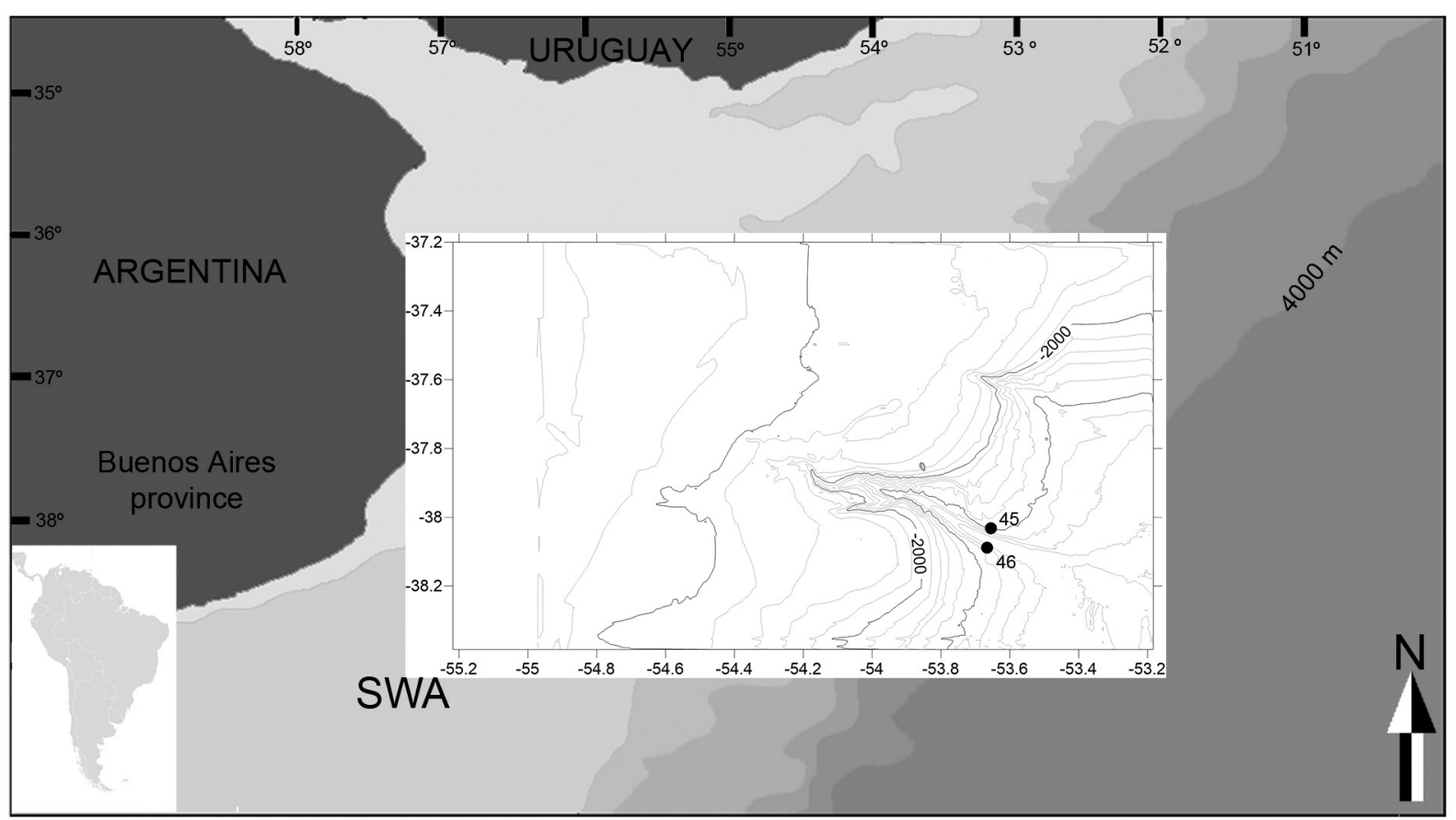

Fig. 1. Distribution of Umbellula pomona Risaro, Williams \& Lauretta sp. nov. in Mar del Plata Submarine Canyon. 
confirmed via 1.5\% agarose gel electrophoresis. PCR products were purified and sequenced in Macrogen, Korea.

\title{
Molecular analysis
}

We added our sequences to the data set used in Dolan et al. (2013) (Table 1), since we are dealing with a deep-sea species of Umbellula (which is the target genus of this work) and no new data on this genus was added in Kushida \& Reimer (2019). All the sequences were downloaded from GenBank, although the mtMutS sequence of Anthoptilum sp. (KF313832) based on a primnoid (as noted by Kushida \& Reimer 2019), so we did not include this sequence in our data matrix. The new sequences were edited using the software Geneious ver. 5.6.7 and checked using BLAST (Altschul et al. 1990) to rule out contamination and to confirm gene identity. The concatenated data set consisted of 41 taxa and $1257 \mathrm{bp}$. Sequence alignment was performed using MAFT (Multiple Alignment using Fast Fourier Transform) ver. 7 (https://mafft.cbrc.jp/alignment/server/) using L-INS-i strategy and default parameters. Trees were built using Bayesian analysis (BA) and maximum likelihood (ML). To determine the evolution model $(\mathrm{GTR}+\mathrm{G}$ and $\mathrm{GTR}+\mathrm{I}+\mathrm{G}$ for mtMuts and ND2, respectively), we implemented the Akaike information criterion (AIC) in PartitionFinder 2 software (Lanfear et al. 2016). Ellisellids were chosen as outgroup (Dolan et al. 2013; Kushida \& Reimer 2019). The Bayesian tree was built using Mrbayes (Ronquist et al. 2012) on Cipres science gateway (Miller et al. 2010): number of runs: 2, number of chains: 4 , number of generations: 100000000 , chain sample frequency: 10000 . The first $25 \%$ of each search was discarded (burninfrac $=0.25$ ). To ensure that the Markov chains reached stationarity (effective sample size values over 200) we used the software Tracer ver. 1.7 (Rambaut et al. 2018). Maximum likelihood analyses were performed using PhyML ver. 3.1 (Guindon et al. 2010) for each individual gene and as a complete set. Bootstrap support was calculated based on 1000 rounds.

\section{Results}

\section{Systematics}

\author{
Phylum Cnidaria Verrill, 1865 \\ Class Anthozoa Ehrenberg, 1834 \\ Subclass Octocorallia Haeckel, 1866 \\ Order Pennatulacea Verrill, 1864 \\ Family Umbellulidae Lindahl, 1874
}

\section{Type genus}

Umbellula Cuvier, 1798.

Diagnosis (adapted from Williams 1990, modifications in bold)

Rachis long and slender. Axis quadrangular to round in cross section. Autozooids restricted to the distal terminus, usually forming an umbellulate cluster. Siphonozooids are present on the rachis at the base of the autozooids or on bare parts of the rachis. Sclerites either present in peduncle, rachis, and terminal cluster, or totally absent. When present, sclerites are rods, spindles or needles, three-flanged round in cross-section.

\section{Included genera}

Umbellula Cuvier, 1798.

\section{Distribution}

Cosmopolitan, from $250 \mathrm{~m}$ to over $6200 \mathrm{~m}$ deep (Williams 2011). 
Table 1 (continued on the next page). GenBank accession numbers of the sequences analyzed in this study. New specimens/sequences in bold. $-=$ data not available $;{ }^{*}=$ data not used (see comment in text). NOCS $=$ National Oceanography Centre, Southampton (UK); $a=$ Natural History Museum (London, $\mathrm{UK}) ; \mathrm{b}=$ NIWA (New Zealand); $\mathrm{c}=$ MACN (Argentina).

\begin{tabular}{|c|c|c|c|c|c|}
\hline Taxon & Location & Depth & Catalogue\# & mtMutS & ND2 \\
\hline \multicolumn{6}{|l|}{ Anthoptilidae } \\
\hline Anthoptilum marrayi & Tasman Sea, AUS & - & - & - & DQ302938 \\
\hline Anthoptilum sp. 1 & Subantarctic & - & $2010.18 \mathrm{a}$ & KF313832* & KF313805 \\
\hline Anthoptilum sp. 2 & Sumatra, Indian Ocean & 1714 & NOCS & - & KF313806 \\
\hline Funiculinidae & & & - & - & - \\
\hline Funiculina armata & NE Atlantic & 350 & $2010.11 \mathrm{a}$ & KF313833 & KF313807 \\
\hline Funiculina quadrangularis & NE Atlantic & 173 & NOCS & KF313834 & - \\
\hline Halipteridae & & & & - & - \\
\hline Halipteris finmarchica & Tasman Sea, AUS & - & - & DQ302868 & DQ302941 \\
\hline Halipteris finmarchica & New Zealand, W Pacific & - & $28801 b$ & KF313835 & KF313808 \\
\hline \multicolumn{6}{|l|}{ Kophobelemnidae } \\
\hline Kophobelemnon macrospinosum & Tasman Sea, AUS & - & - & DQ302865 & DQ302937 \\
\hline Kophobelemnon pauciflorum & Crozet, S Atlantic & 4189 & $2010.21 \mathrm{a}$ & KF313836 & KF313809 \\
\hline Kophobelemnon sp. 1 & Koster Channel, NE Atlantic & 70 & $2010.13 \mathrm{a}$ & KF313837 & KF313810 \\
\hline Kophobelemnon sp. 2 & Monterey, E Pacific & 2456 & $2010.10 \mathrm{a}$ & KF313838 & KF313811 \\
\hline Kophobelemnon sp. 3 & New Zealand, W Pacific & 1812 & $28827 b$ & KF313839 & KF313812 \\
\hline Sclerobelemnon theseus & Colombia & - & - & DQ311679 & DQ311678 \\
\hline \multicolumn{6}{|l|}{ Pennatulidae } \\
\hline Pennatula aculeata & Monterey, E Pacific & 2456 & $2010.15 \mathrm{a}$ & KF313840 & KF313813 \\
\hline Pennatula phosphorea & Millport, NE Atlantic & 55 & NOCS & KF313841 & KF313814 \\
\hline Pennatula murray & Monterey, E Pacific & 3208 & $2010.9 a$ & KF313842 & KF313815 \\
\hline Pennatula sp. & Tasman Sea, AUS & - & - & DQ302870 & DQ302943 \\
\hline \multicolumn{6}{|l|}{ Protoptilidae } \\
\hline Distichoptilum gracile & Tasman Sea, AUS & - & - & DQ302866 & DQ302939 \\
\hline Distichoptilum gracile & New Zealand, W Pacific & 1211 & $28813 b$ & KF313843 & KF313816 \\
\hline Distichoptilum gracile & Monterey, E Pacific & 2456 & NOCS & - & KF313817 \\
\hline Protoptilum sp. & Monterey, E Pacific & 3208 & $2010.20 \mathrm{a}$ & KF313844 & KF313818 \\
\hline \multicolumn{6}{|l|}{ Pteroeididae } \\
\hline Gyrophyllum sp. & NE Atlantic & 1580 & NOCS & KF313845 & - \\
\hline Gyrophyllum sp. & New Zealand, W Pacific & 997 & $28779 b$ & KF313846 & KF313819 \\
\hline Pteroeides sp. & Tasman Sea, AUS & - & - & DQ302871 & DQ302944 \\
\hline \multicolumn{6}{|l|}{ Renillidae } \\
\hline Renilla muelleri & GOM, Florida, USA & - & - & DQ297432 & DQ297451 \\
\hline \multicolumn{6}{|l|}{ Scleroptilidae } \\
\hline Scleroptilum grandiflorum & Mid-Atlantic Ridge & 2190 & $2010.14 a$ & KF313847 & KF313820 \\
\hline
\end{tabular}


Table 1 (continued). GenBank accession numbers of the sequences analyzed in this study. New specimens/sequences in bold. $-=$ data not available; $*=$ data not used (see comment in text). NOCS $=$ National Oceanography Centre, Southampton (UK); $a=$ Natural History Museum (London, UK); $b=$ NIWA (New Zealand); $\mathrm{c}=$ MACN (Argentina).

\begin{tabular}{|c|c|c|c|c|c|}
\hline Taxon & Location & Depth & Catalogue\# & mtMutS & ND2 \\
\hline \multicolumn{6}{|l|}{ Umbellulidae } \\
\hline Umbellula carpenteri & Crozet, S Atlantic & 4189 & NOCS & KF313848 & KF313821 \\
\hline Umbellula encrinus & Arctic Ocean & 1400 & $2010.8 \mathrm{a}$ & KF313849 & KF313822 \\
\hline Umbellula huxleyi & NE Atlantic & 1512 & $2010.17 \mathrm{a}$ & KF313850 & KF313823 \\
\hline Umbellula magniflora & Marguerite Bay, Antarctica & 840 & $2010.22 \mathrm{a}$ & KF313851 & KF313824 \\
\hline Umbellula monocephalus & Indian ocean & 4229 & $2010.16 \mathrm{a}$ & KF313852 & KF313825 \\
\hline Umbellula thomsoni 1 & Crozet, S Atlantic & 4189 & 2010.19a & KF313853 & KF313826 \\
\hline Umbellula thomsoni 2 & $\begin{array}{l}\text { Cascais Canyon, } \\
\text { NE Atlantic }\end{array}$ & 3476 & NOCS & KF313854 & KF313827 \\
\hline Umbellula sp. 1 & $\begin{array}{l}\text { Whittard Canyon, } \\
\text { NE Atlantic }\end{array}$ & 4040 & $2009.8 \mathrm{a}$ & KF313855 & KF313828 \\
\hline Umbellula sp. 2 & Crozet, S Atlantic & 4189 & 2009.6a & KF313856 & KF313829 \\
\hline $\begin{array}{l}\text { Umbellula pomona sp. nov. } \\
\text { (holotype) }\end{array}$ & $\begin{array}{l}\text { Mar del Plata Submarine } \\
\text { Canyon, SAO }\end{array}$ & 2934 & $42608 \mathrm{c}$ & MT467665 & - \\
\hline $\begin{array}{l}\text { Umbellula pomona sp. nov. } \\
\text { (paratype) }\end{array}$ & $\begin{array}{l}\text { Mar del Plata Submarine } \\
\text { Canyon, SAO }\end{array}$ & 3282 & $42609 \mathrm{c}$ & - & MT467666 \\
\hline \multicolumn{6}{|l|}{ Virgulariidae } \\
\hline Virgularia mirabilis & Sweden, NE Atlantic & 36.5 & $2010.7 \mathrm{a}$ & KF313857 & KF313830 \\
\hline Virgularia mirabilis & $\begin{array}{l}\text { Portland, UK, } \\
\text { NE Atlantic }\end{array}$ & 12 & 2010.23a & KF313858 & KF313831 \\
\hline \multicolumn{6}{|l|}{ Outgroup: Ellisellidae } \\
\hline Ctenocella barbadensis & Unknown & - & - & - & AY534736 \\
\hline Verrucella sp. & Unknown & - & - & - & DQ302936 \\
\hline
\end{tabular}

\section{Remarks}

Since sclerites were found in the rachis of U. pomona sp. nov., we added this character to the family diagnosis.

\section{Genus Umbellula Cuvier, 1798}

\section{Type species}

Isis encrinus Linnaeus, 1758.

\section{Diagnosis}

Same characteristics of the family.

Valid species (based on Broch 1957; Williams 1995; López-González \& Williams 2011)

Umbellula encrinus (Linnaeus, 1758), Umbellula lindahli Kölliker, 1874, Umbellula thomsoni Kölliker, 1874, Umbellula carpenteri Kölliker, 1880, Umbellula durissima Kölliker, 1880, Umbellula huxleyi 
Kölliker, 1880, Umbellula pellucida Kükenthal, 1902, Umbellula spicata Kükenthal, 1902, Umbellula hemigymna Pasternak, 1975, Umbellula monocephalus Pasternak, 1964, Umbellula pomona sp. nov.

\title{
Remarks
}

Although in his revision of the family, Broch (1958) synonymized Umbellula dura Thomson \& Henderson, 1906 with Umbellula durissima Kölliker, 1880 and Umbellula rosea Thomson \& Henderson, 1906 with Umbellula thomsoni Kölliker, 1880, we consider that, based on the original descriptions and images of $U$. dura and $U$. rosea, those species have important morphological characters to compare with our specimens.

\author{
Umbellula pomona Risaro, Williams \& Lauretta sp. nov. \\ urn:1sid:zoobank.org:act:77FCDEF4-AAE3-4BB5-BAB2-1EDAA4B19439
}

Figs $2-7$

\section{Differential diagnosis}

Umbellula pomona sp. nov. is a spiculated Umbellula with three autozooids in its terminal cluster, a central well-developed polyp and two lateral, symmetric and smaller ones. It presents large sclerites in all its tissues as well as siphonozooids all along the rachis. Its central axis is circular in cross section all along its extension, and does not vary throughout the colony.

\section{Etymology}

The species is named after the birthplace of the first author (JR), Pomona (Río Negro, Argentina). The word 'pomona' is used as a noun in opposition.

\section{Material examined}

\section{Holotype}

SW ATLANTIC OCEAN • one complete spec. (preserved in 96\% ethanol); Mar del Plata Submarine Canyon, “Talud Continental III" exped., stn N 45; 38¹.913' S, 53³9.268’ W; 2934 m deep; Sep. 2013; Daniel Lauretta leg.; MACN-IN 42608.

\section{Paratypes}

SW ATLANTIC OCEAN - 3 specs (two adult, without the peduncle: paratypes A and B; and one juvenile like, complete: paratype C; preserved in 96\% ethanol); Mar del Plata Submarine Canyon, “Talud Continental III" exped., stn $\mathrm{N}^{\circ} 46$; 38 5.310' S, 53³9.988' W; 3282 m deep; Sep. 2013; Daniel Lauretta leg.; MACN-IN 42609.

\section{Description (holotype MACN-IN 42608)}

The colony looks rugous in all its extension, especially the terminal cluster of autozooids. The color of the polyps, rachis and the peduncle is white or light yellow (preserved). The holotype is $214 \mathrm{~mm}$ in length. It has a terminal cluster of three autozooids with tentacles, one central and larger polyp growing on the distal-most region of the rachis, and two smaller but well-developed lateral polyps growing at the base of the central one (Fig. 2). The central polyp is $25.3 \mathrm{~mm}$ in length and the two lateral polyps' lengths are $3.0 \mathrm{~mm}$ and $2.6 \mathrm{~mm}$. The tentacles of the two types of polyps are larger than its body, the measures are $12.3 \mathrm{~mm}$ for the central autozooid, and $1.1 \mathrm{~mm}$ and $1.7 \mathrm{~mm}$ for the lateral ones. The axis is $178 \mathrm{~mm}$ in length and it is circular in cross-section, approximately $0.74 \mathrm{~mm}$ in diameter. The rachis is approximately $0.8 \mathrm{~mm}$ in diameter in the middle zone between the peduncle and the terminal cluster. The peduncle is $8.68 \mathrm{~mm}$ in length, and its appearance is soft and smooth. The autozooids of the cluster grow with a kind of orientation determining a 'dorsal' region where the axis inserts and a 'ventral' 

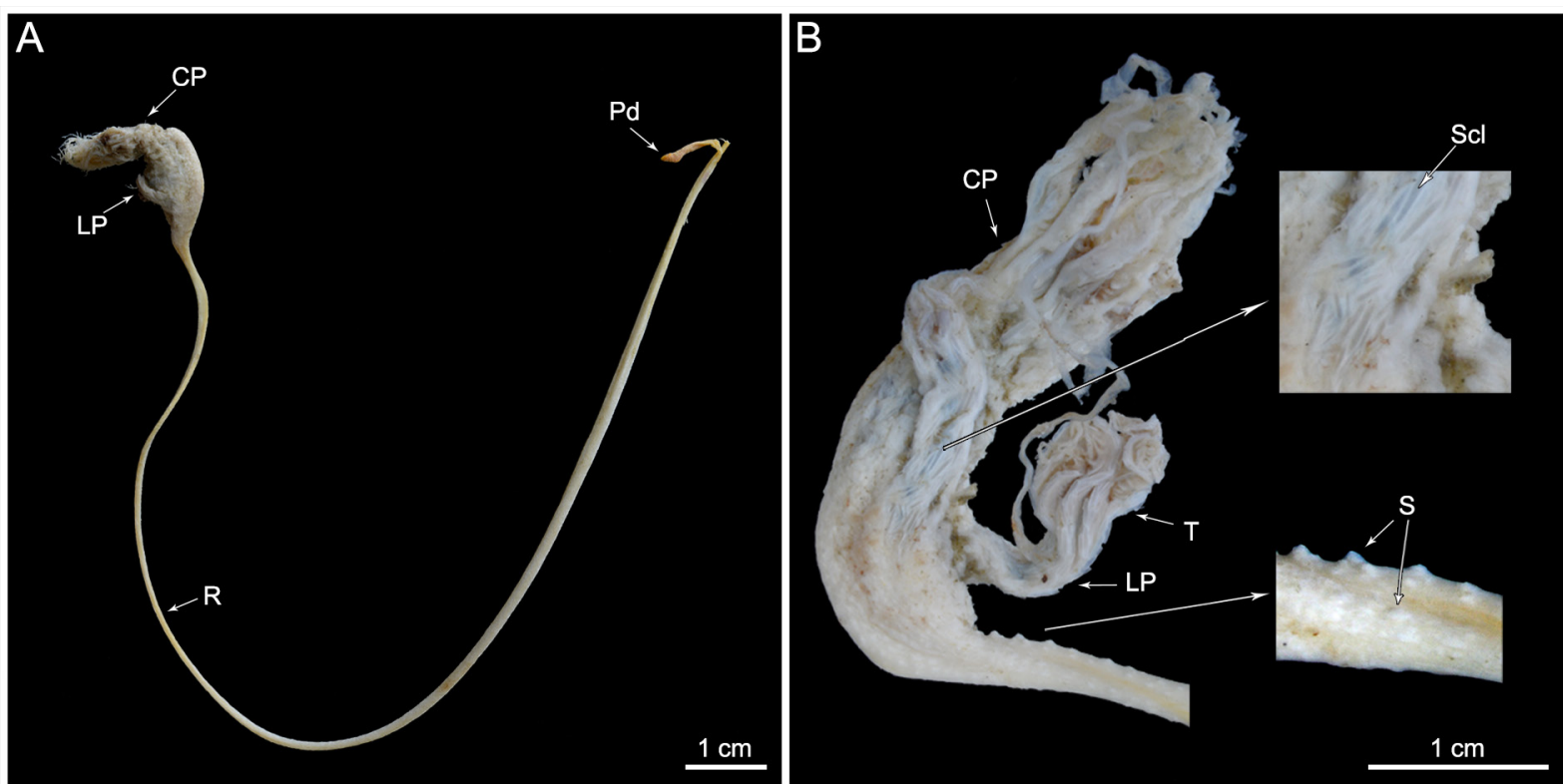

Fig. 2. A. General aspect of Umbellula pomona Risaro, Williams \& Lauretta sp. nov. A. Holotype (MACN-IN 42608). B. Detail of the terminal cluster of paratype A (MACN-IN 42609), showing three autozooids that form the terminal cluster and amplifications of sclerites (up) and siphonozooids (down). Abbreviations: $\mathrm{CP}=$ central polyp; $\mathrm{LP}=$ lateral polyp; $\mathrm{Pd}=$ peduncle; $\mathrm{R}=$ rachis; $\mathrm{T}=$ tentacle; $\mathrm{S}=$ siphonozooids; $\mathrm{Scl}=$ sclerites.
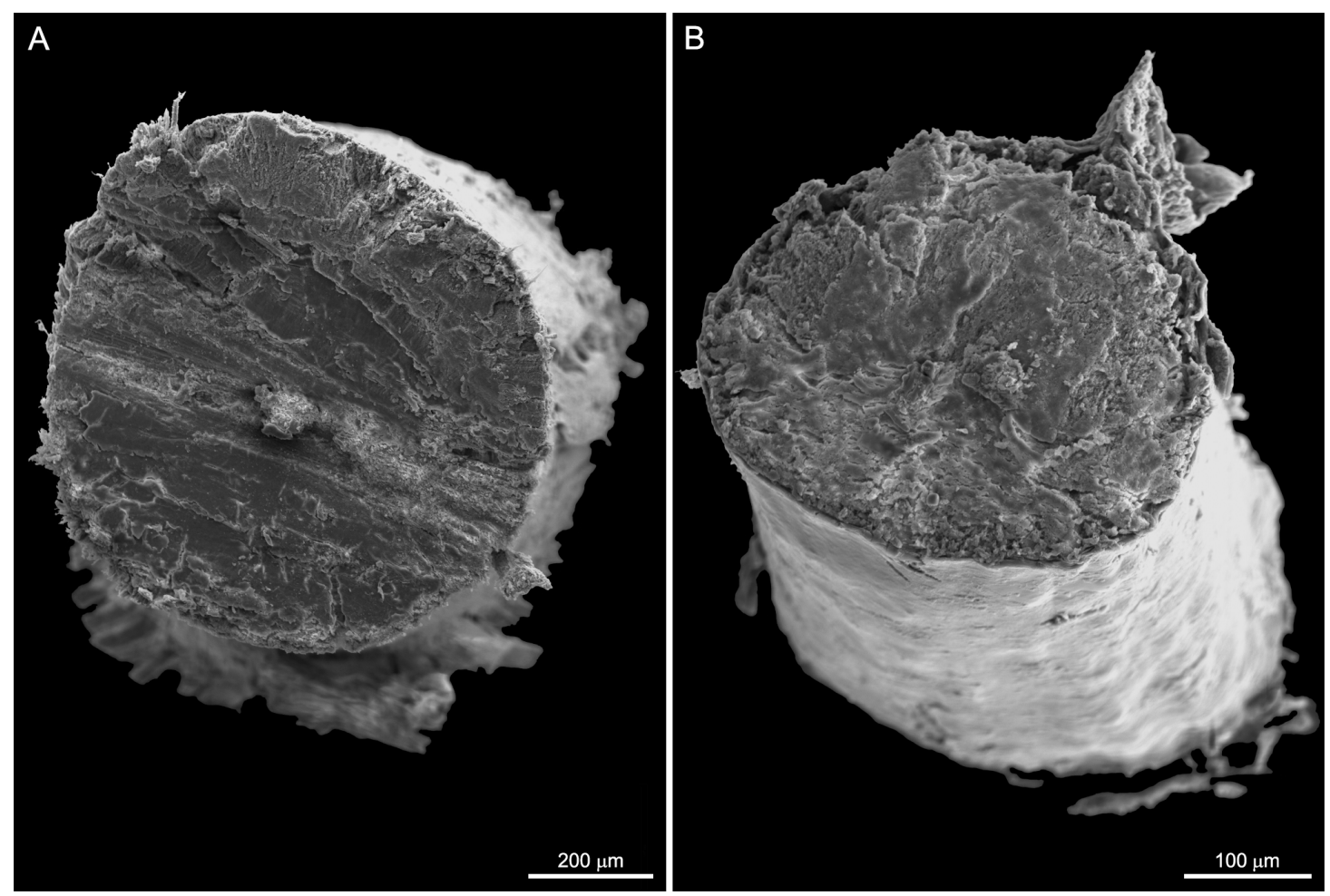

Fig. 3. Transversal section of the central axis of paratype B of Umbellula pomona Risaro, Williams \& Lauretta sp. nov. (MACN-IN 42609). A. Transversal section of the central axis between the peduncle and the rachis. B. Transversal section of the central axis near the terminal cluster. 
region towards which the polyps come together (Fig. 2). The siphonozooids are numerous and resemble small white dots, and are distributed all along the rachis from the base of the autozooids to the middle of the rachis. These polyps are circular and inconspicuous; and have a diameter of about $393 \pm 93 \mu \mathrm{m}$ $(299-486 \mu \mathrm{m}, \mathrm{N}=36)$.

Sclerites are conspicuous, along much of the length of the colony (polyps, rachis, tentacles and pinnules). They are translucent and colorless, rod-shaped and spindle-shaped with spines (Figs 4-7). Those present in the rachis are spindle-shaped, have triangular protuberances all along their length (Fig. 4) and their sizes are $333.5 \pm 71.1 \mu \mathrm{m}(262.4-404.6 \mu \mathrm{m}, \mathrm{N}=10)$, the body wall of the polyps has different types of sclerites, two of them are rough and rod-shaped, but differ in their measurements, while the others are spindle-shaped with spines along their lengths and also have different sizes (Fig. 5). The largest type is rod-shaped and approximates $1446 \pm 32.7 \mu \mathrm{m}(1413.3-1478.7 \mu \mathrm{m}, \mathrm{N}=5)$ in length (Fig. 5A); another type, smaller and spine-shaped, approximates $687 \pm 45.6 \mu \mathrm{m}(641.4-732.6 \mu \mathrm{m}, \mathrm{N}=5)$ (Fig. 5B-C). The other types are much smaller, and one type is rod shaped, like the largest one (Fig. 5D), and the other
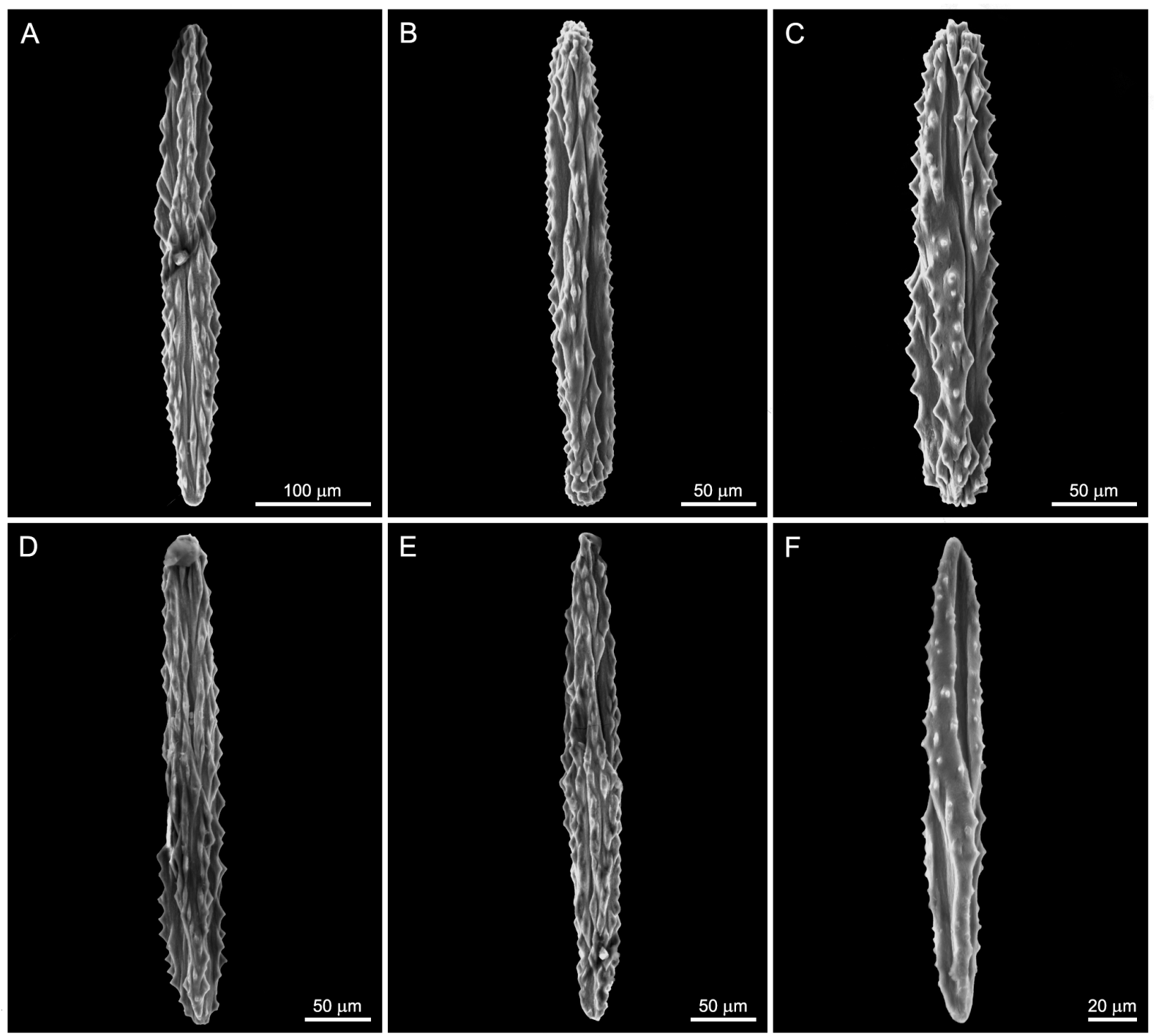

Fig. 4. Variability of sizes and ornamentations of the rachis' sclerites of the holotype of Umbellula pomona Risaro, Williams \& Lauretta sp. nov. (MACN-IN 42608). 
type is spine-shaped (Fig. 5E-F); these two types of sclerites have similar sizes, length approximates $534 \pm 43.4 \mu \mathrm{m}(490.6-577.4 \mu \mathrm{m}, \mathrm{N}=5)$. Finally, the tentacles have rod-shaped sclerites (Fig. 6) with two sizes: the larger ones are $1223.2 \pm 280.1 \mu \mathrm{m}(943.1-1503.3 \mu \mathrm{m}, \mathrm{N}=5)$ (Fig. 6A-C) and the smaller ones are $632.8 \pm 96.2 \mu \mathrm{m}(536.6-729 \mu \mathrm{m}, \mathrm{N}=5)$ in length (Fig. 6D-F), and those of the pinnules are rod-shaped with some protuberances along their lengths and their sizes are approximately $269.1 \pm$ $50.3 \mu \mathrm{m}(218.8-319.4 \mu \mathrm{m}, \mathrm{N}=10)$ (Fig. 7). In both tissues the sclerites are placed along the main axis, not transversally.

\section{Variability}

Of the three paratypes (A, B and C), one (paratype C) is significantly smaller than the others, so we consider it could be a juvenile (Fig. 8). The color of the three colonies is white or light yellow when preserved, all of them have three autozooids with the same grade of development as the holotype (as it can be seen in Fig. 2B) and its central axis is round in all its extension (Fig. 3). The large paratypes (A and B) lack their peduncle. Their general aspect is just like the holotype, they are rugous in all their
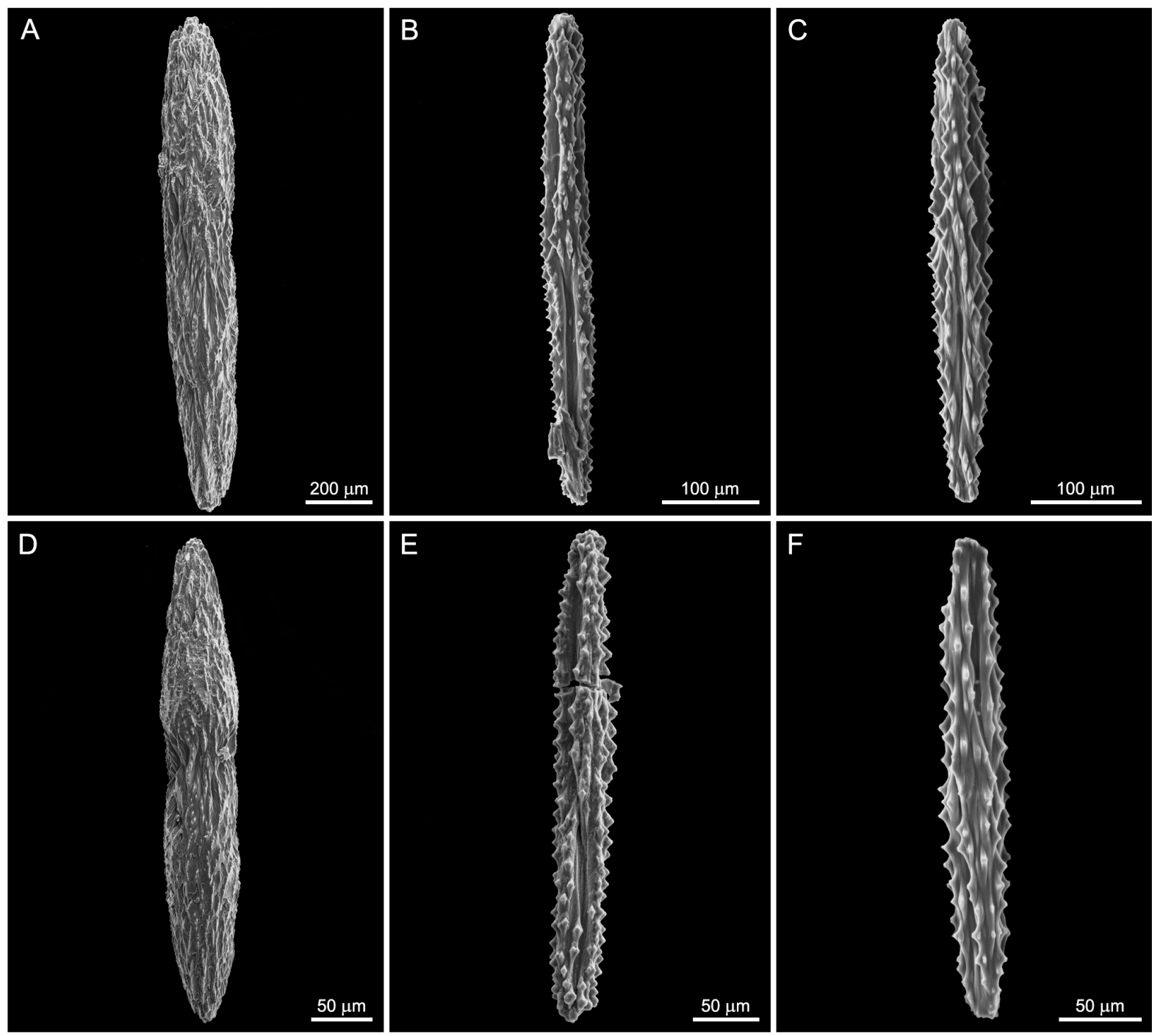

Fig. 5. Variability of sizes and ornamentations of the polyps' sclerites of the holotype of Umbellula pomona Risaro, Williams \& Lauretta sp. nov. (MACN-IN 42608). 
length because of the presence of conspicuous sclerites in the autozooids and rachis (Fig. 2B). The total length of the large paratypes is $134 \mathrm{~mm}$ and $231 \mathrm{~mm}$, their central autozooids are $36 \mathrm{~mm}$ and $34 \mathrm{~mm}$ long (length of the tentacles: $20 \mathrm{~mm}$ and $12 \mathrm{~mm}$, length of the columns: $16 \mathrm{~mm}$ and $22 \mathrm{~mm}$, respectively) while the dimensions of the lateral ones are $4.8 \mathrm{~mm}$ and $5.6 \mathrm{~mm}$ in one paratype and $6.4 \mathrm{~mm}$ and $7 \mathrm{~mm}$ in the other. Their rachis are $97 \mathrm{~mm}$ and $200 \mathrm{~mm}$ in length and their diameters are $0.9 \mathrm{~mm}$ and $2.2 \mathrm{~mm}$ at thier widest sections. Their axis' diameter is $0.83 \mathrm{~mm}$ and $1.3 \mathrm{~mm}$. Their siphonozooids are $313 \mu \mathrm{m}$ and $370 \mu \mathrm{m}$ (mean) in diameter and look like the siphonozooids of the holotype. Finally, the sclerites of these paratypes look alike and have similar sizes as the sclerites of the holotype. The juvenile paratype's (C) total length is $110 \mathrm{~mm}$, its central autozooid is $7.9 \mathrm{~mm}$ in length (column and tentacles are $4.4 \mathrm{~mm}$ and $3.4 \mathrm{~mm}$ long, respectively), and the length of the lateral ones is $2.9 \mathrm{~mm}$ (column and tentacles are 1.4 and $1.5 \mathrm{~mm}$ in length, respectively). The peduncle's length is $4.6 \mathrm{~mm}$ and the rachis' $95 \mathrm{~mm}$, while its diameter is $0.41 \mathrm{~mm}$ at its widest section. Its central axis is $0.35 \mathrm{~mm}$ in diameter. Finally, the siphonozooids of this paratype are tiny spots with the same aspect and distribution as those on the holotype and the largest paratypes.
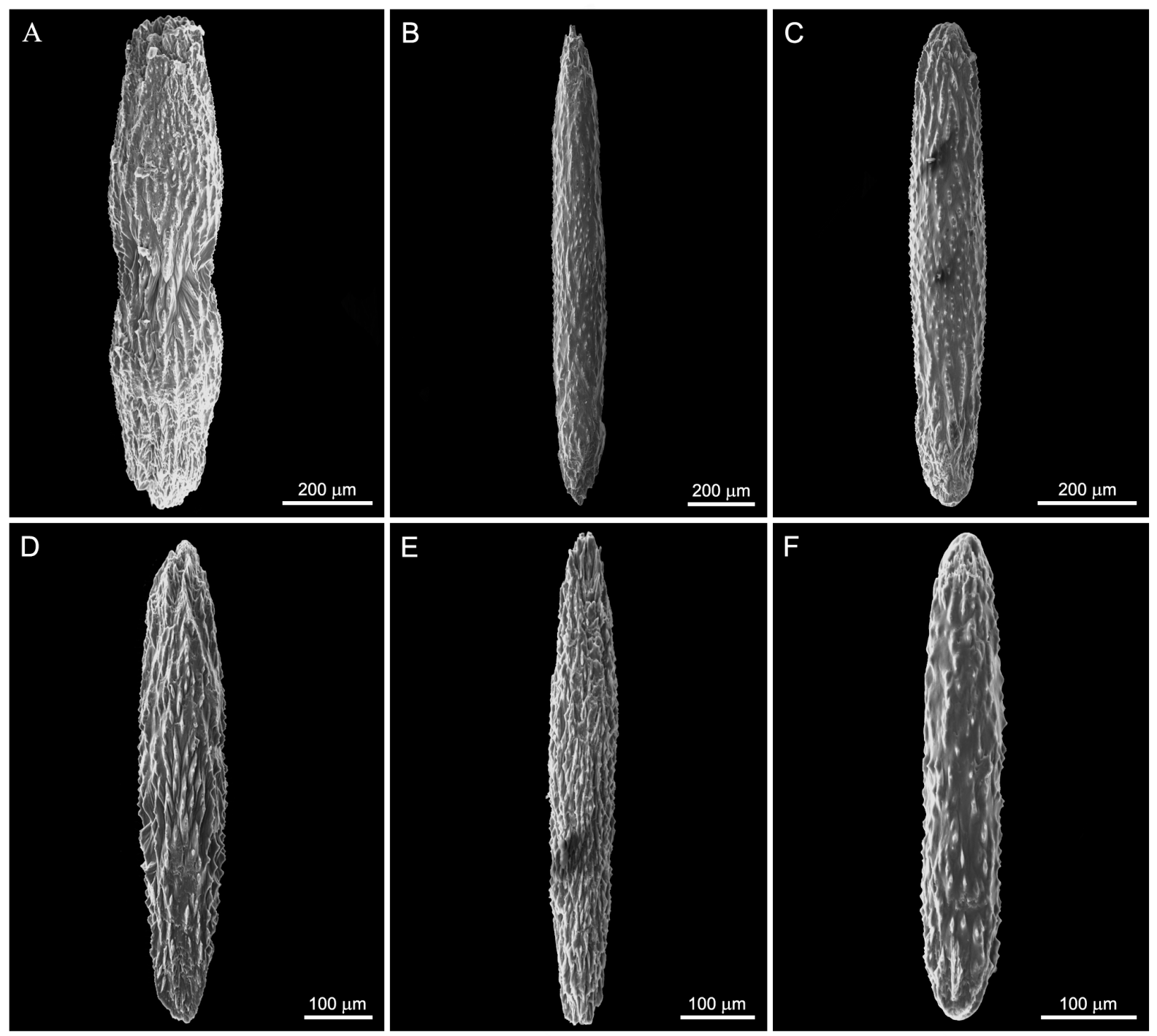

Fig. 6. Variability of sizes and ornamentations of the tentacles' sclerites of the holotype of Umbellula pomona Risaro, Williams \& Lauretta sp. nov. (MACN-IN 42608). 


\section{Phylogenetic analysis}

Both phylogenetics reconstructions (i.e., BA and ML) agree in the basic topology of the trees (for simplicity we only show BA). Both type specimens of $U$. pomona sp. nov. were grouped together with low support values within the same group (possibly because we only have one gene sequence for each species). Umbellula spp. were recovered in two clusters, Umbellula clade I including most of the included Umbellula species and a second one (Umbellula clade II) including only U. monocephalus, Umbellula pomona sp. nov. and Umbellula sp. 2 from Dolan et al. (2013) (Fig. 9).

\section{Discussion}

\section{Regarding Umbellula pomona sp. nov.}

As currently defined, our specimens agree with the current set of characters assigned to Umbellula. They have a long, slender rachis, a cluster of autozooids on their distal-most part and numerous siphonozooids all along the rachis, in addition to conspicuous, rod- or needle-like sclerites. Chunella Kükenthal, 1902

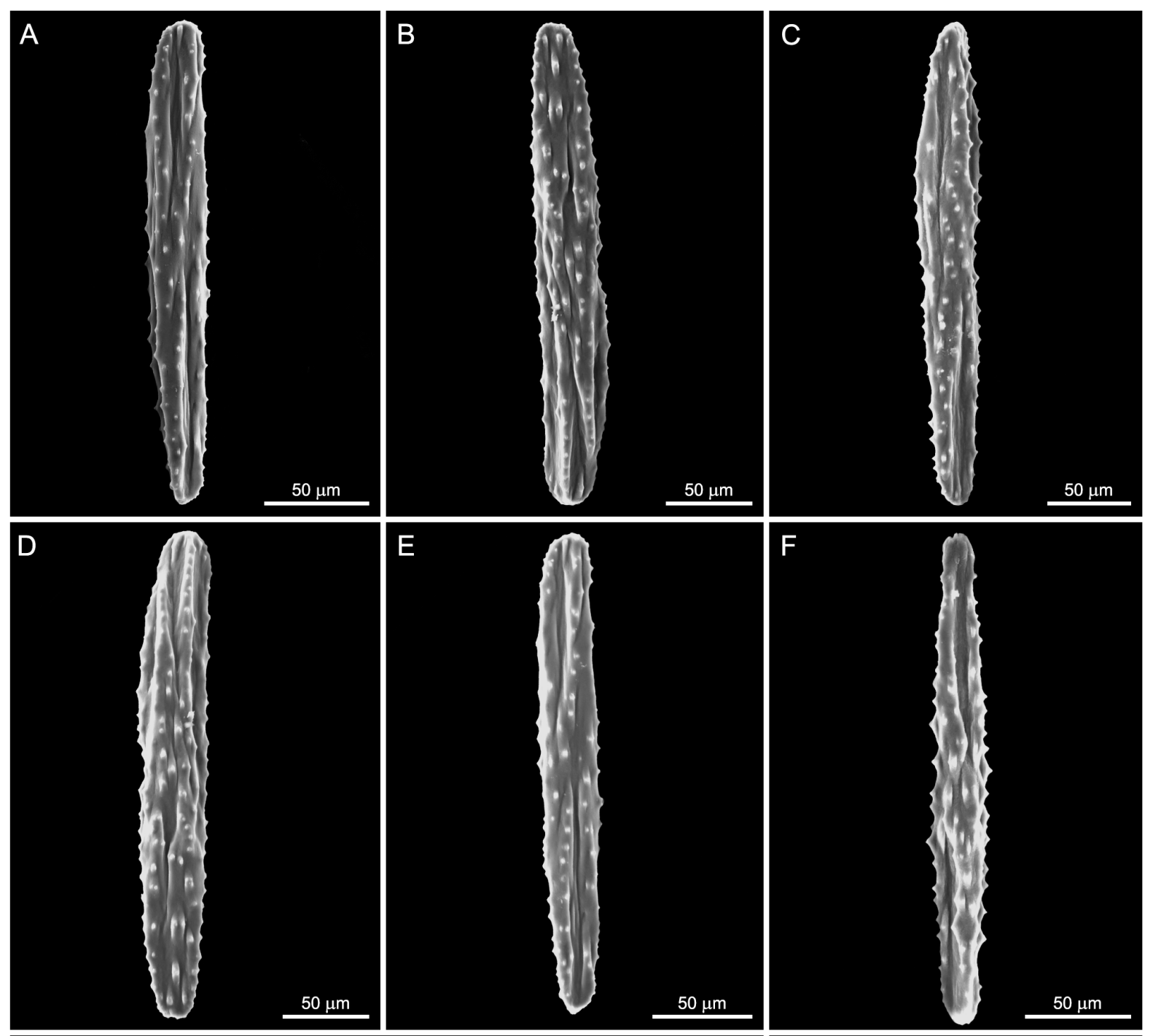

Fig. 7. Variability of sizes and ornamentations of the pinnules' sclerites of the holotype of Umbellula pomona Risaro, Williams \& Lauretta sp. nov. (MACN-IN 42608). 
and Amphiacme Kükenthal, 1902 are other similar genera, but have several polyp clusters disposed in intervals along the rachis and do not have sclerites (Kükenthal 1915).

From a morphological point of view, there are two major species groups in the genus Umbellula, based on the presence/absence of sclerites. Up to date, of all described species, five are spiculate (of which only three are probably valid) whose morphology needs to be compared: $U$. thomsoni, $U$. durissima, $U$. dura, $U$. rosea and U. monocephalus. None of them share the diagnostic set of characters (arrangement of the polyp cluster, form of the central axis and sclerite sizes) of our specimens (Table 2). Umbellula pomona sp. nov. has a reduced number of polyps, forming a terminal cluster with one central autozooid and two smaller, lateral ones growing from its base, a cylindrical central axis, and the sizes of thier sclerites range from $1446 \mu \mathrm{m}$ to $269.1 \mu \mathrm{m}$, depending on location in the tissues. Umbellula thomsoni has been reported with three to ten autozooids in its terminal cluster growing like a flower or an umbrella, with a similar grade of development among them. The axis of this species differs in its shape in cross section, as near the cluster it is quadrangular, while it becomes cylindrical near the peduncle. Its sclerites vary from approximately $1300 \mu \mathrm{m}$ (pinnules and tentacles) to less than $300 \mu \mathrm{m}$ (rachis and body wall of the polyps) (Kükenthal 1915; Williams 1990). Umbellula monocephalus has only one polyp in the distal region of the rachis (Pasternak 1964; Grasshoff 1972; Tiefenbacher 2001). Umbellula durissima has
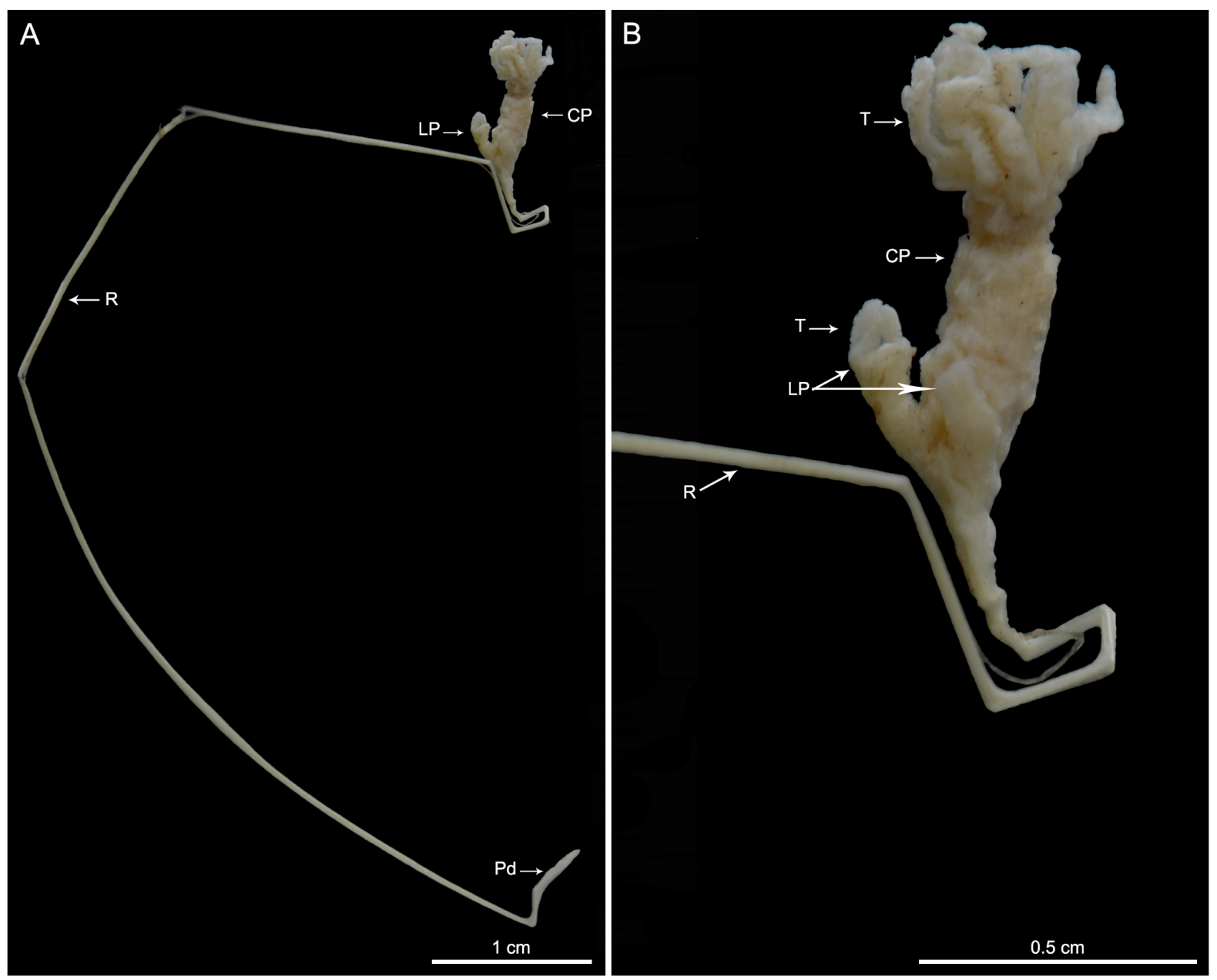

Fig. 8. General aspect of the unique specimen of a juvenile-like paratype of Umbellula pomona Risaro, Williams \& Lauretta sp. nov. (MACN-IN 42609, paratype C). Abbreviations: CP = central polyp; LP = lateral polyp; $\mathrm{R}=$ rachis; $\mathrm{PD}=$ peduncle; $\mathrm{T}=$ tentacles. 


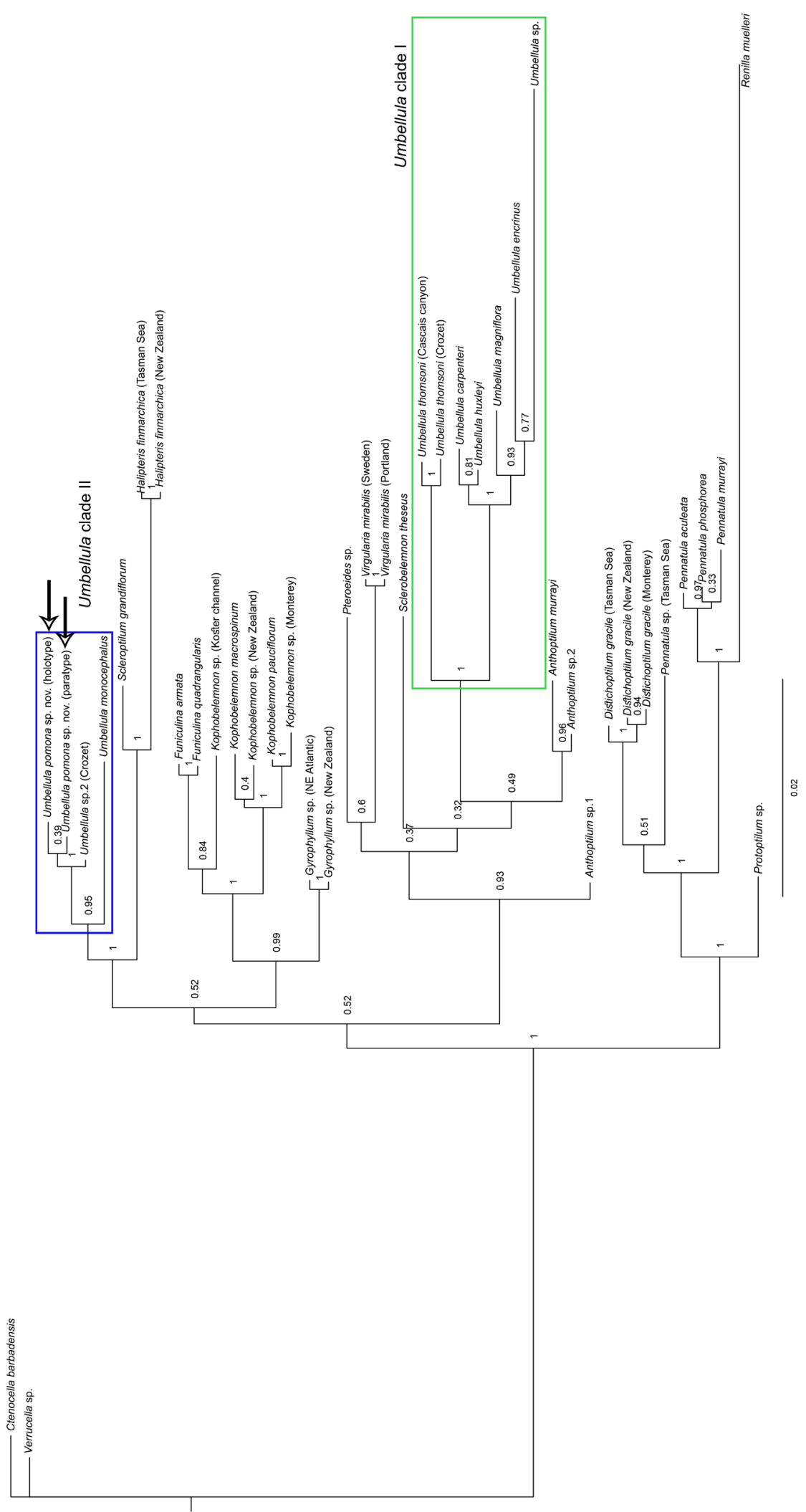

Fig. 9. Phylogenetic reconstruction of the concatenated set of the two mitochondrial genes (mtMutS and ND2) based on the Bayesian analysis. Nodes include the Bayesian posterior probabilities. Arrows point to the new specimens of Umbellula Cuvier, 1798 included in the analysis. 


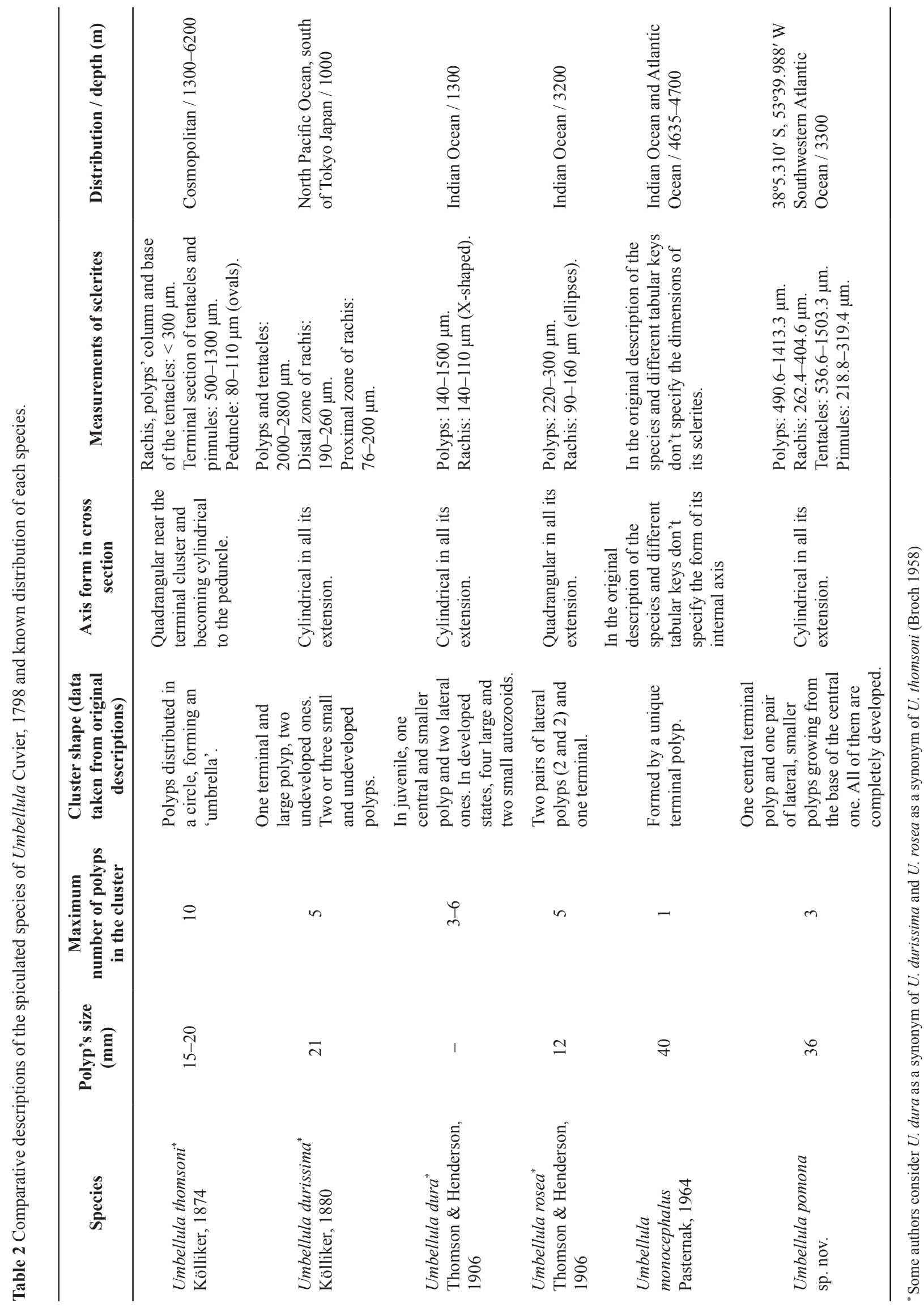


numerous polyps forming an apical cluster of three autozooids, one terminal and well developed, two lateral and two or three less developed ones (without tentacles) below the principal cluster. Its central axis is cylindrical in all its length. The sclerites vary in length from $2800 \mu \mathrm{m}$ (body wall of the polyps and tentacles) to approximately $200 \mu \mathrm{m}$ (rachis), additionally, this species does not have siphonozooids along the rachis, but they are grouped between the autozooids in the terminal cluster (Kölliker 1880; Thomson \& Henderson 1906; Kükenthal 1915). Umbellula dura has three autozooids growing at the same level forming a kind of circle in which the central autozooid is smaller than the other laterals in juvenile states, but in more developed states have six autozooids in total, four large and two very small, all disposed in three sets. Its central axis is cylindrical in cross section and the sclerites vary in length from $1500 \mu \mathrm{m}$ to $300 \mu \mathrm{m}$ in the autozooids and from $140 \mu \mathrm{m}$ to $100 \mu \mathrm{m}$ in the rachis, also, in these tissue has $\mathrm{X}$-shaped sclerites (Thomson \& Henderson 1906), that are absent in U. pomona sp. nov. Umbellula rosea is the more similar species to U. pomona sp. nov., but it can be differentiated because although it has a central terminal polyp and two pairs of lateral autozooids below it, the axis of $U$. rosea is quadrangular in cross section throughout (Thomson \& Henderson 1906) while the axis of U. pomona sp nov. is cilindrycal in all its extention. In addition, Kükenthal (1915: 54), and Thomson \& Henderson (1906: 5) describe the presence of small, thick, oval sclerites in the peduncle of $U$. rosea, which are absent in U. pomona sp. nov. Finally, some paratypes of $U$. rosea have just a few sclerites in their autozooids' tissue of around 250 $\mu \mathrm{m}$ long (Thomson \& Henderson, 1906) while U. pomona sp. nov. has very numerous and conspicuous sclerites in these tissues, from $1446 \mu \mathrm{m}$ to $543 \mu \mathrm{m}$ long. Some paratypes of $U$. pomona sp. nov. have oocytes, which confirms that these are adult specimens. In consequence, we describe here a new species for our specimens. A summary of all diagnostic characters is presented in Table 2.

Umbellula pomona sp. nov. inhabits the deep region of Mar del Plata Submarine Canyon, at a depth of about $3000 \mathrm{~m}$. Sixty-four sampling stations were established during three expeditions, from $200 \mathrm{~m}$ to $3500 \mathrm{~m}$ deep, over 150 specimens of sea pens were collected but only four specimens of the new species were found. This low number of specimens is not rare because in the study area, many species report a very low abundance. Many deep-sea invertebrate species from Mar del Plata Submarine Canyon have been registered/described based on a few (and even only one) specimens (Pastorino 2016; Lauretta \& Penchaszadeh 2017; Martinez et al. 2019). Since sampling efforts in this area have been almost nonexistent until a few years ago, the number of species of sea pens (and other invertebrates) from Mar del Plata Submarine Canyon is likely to increase substantially in the coming years.

\section{Phylogenetic position of Umbellula pomona sp. nov.}

In all the phylogenetic reconstructions made, both specimens of $U$. pomona sp. nov. were grouped together (with low support, since we could only amplify one different gene for each specimen). They were grouped within a cluster composed by only two other species of Umbellula: U. monocephalus and U. sp. 2 (from Dolan 2008; Dolan et al. 2013). Unfortunately, no molecular data of U. rosea, U. durissima or $U$. dura (the most morphologically similar species to $U$. pomona sp. nov.) were available, so it was impossible to compare the species from the molecular point of view.

There are only two molecular phylogenies available for sea pens that include several species and families (i.e., Dolan et al. 2013; Kushida \& Reimer 2019). Both were constructed using two mitochondrial genes (mtMutS and ND2), and the latter was an extension of the former, including shallow-water species. Both papers agree that Umbellula is a polyphyletic group, with two clearly separate clades (here 'Umbellula clade I' and 'Umbellula clade II'). 'Umbellula clade I' includes most of the species of Umbellula with available molecular data, including U. encrinus, the type species of the genus. 'Umbellula clade II' includes only three species: U. monocephalus (an atypical Umbellula since it has only one terminal polyp), U. pomona sp. nov. (also an atypical species since the polyps have different sizes) and a nonidentified Umbellula sp. (Umbellula sp2 from Dolan et al. 2013) with a typical polyp cluster (according to the figure in Dolan 2008). According to Dolan et al. (2013), 'Umbellula clade II' was characterized by 
RISARO J. et al., New sea pen from Mar del Plata Submarine Canyon

Table 3. Distribution of the currently considered valid species of the genus Umbellula Cuvier, 1798.

\begin{tabular}{|c|c|c|c|}
\hline Species & $\begin{array}{c}\text { Presence } \\
\text { of sclerites }\end{array}$ & Distribution & Main references \\
\hline $\begin{array}{l}\text { Umbellula encrinus } \\
\text { (Linnaeus, 1758) }\end{array}$ & No & Arctic Ocean & $\begin{array}{l}\text { Linnaeus 1758; } \\
\text { Kükenthal 1911, 1915; } \\
\text { Williams } 1995\end{array}$ \\
\hline $\begin{array}{l}\text { Umbellula thomsoni } \\
\text { Kölliker, } 1874\end{array}$ & Yes & Cosmopolitan & $\begin{array}{l}\text { Kölliker 1874; } \\
\text { Kükenthal 1911, 1915; } \\
\text { Williams } 2011\end{array}$ \\
\hline $\begin{array}{l}\text { Umbellula carpenteri } \\
\text { Kölliker, } 1880\end{array}$ & No & $\begin{array}{l}\text { Antarctic Ocean, } \\
\text { Antarctic Indian Ocean }\end{array}$ & $\begin{array}{l}\text { Kölliker } 1880 \text {; } \\
\text { López-González \& } \\
\text { Williams } 2011\end{array}$ \\
\hline $\begin{array}{l}\text { Umbellula durissima } \\
\text { Kölliker, } 1880\end{array}$ & Yes & $\begin{array}{l}\text { North Western Pacific Ocean, } \\
\text { East Indian Ocean, North Atlantic, } \\
\text { West Atlantic and South Atlantic } \\
\text { Ocean, Antarctic Ocean }\end{array}$ & $\begin{array}{l}\text { Kölliker 1880; } \\
\text { Kükenthal 1915; } \\
\text { Broch 1958; } \\
\text { Williams } 1995\end{array}$ \\
\hline $\begin{array}{l}\text { Umbellula huxleyi } \\
\text { Kölliker, } 1880\end{array}$ & No & $\begin{array}{l}\text { North Pacific Ocean, East Indian } \\
\text { Ocean, North Atlantic and South } \\
\text { Eastern Atlantic Ocean }\end{array}$ & $\begin{array}{l}\text { Kölliker 1880; } \\
\text { Kükenthal 1915; } \\
\text { Broch 1958; } \\
\text { Williams 1995; } \\
\text { López-González \& } \\
\text { Williams } 2011\end{array}$ \\
\hline $\begin{array}{l}\text { Umbellula pellucida } \\
\text { Kükenthal, } 1902\end{array}$ & No & North Indian Ocean & $\begin{array}{l}\text { Kükenthal 1902, 1915; } \\
\text { Broch 1958; } \\
\text { Williams 1995 }\end{array}$ \\
\hline $\begin{array}{l}\text { Umbellula spicata } \\
\text { Kükenthal, } 1902\end{array}$ & No & Indian Ocean & $\begin{array}{l}\text { Kükenthal 1902, 1915; } \\
\text { Broch 1958; } \\
\text { Williams 1995 }\end{array}$ \\
\hline $\begin{array}{l}\text { Umbellula monocephalus } \\
\text { Pasternak, } 1964\end{array}$ & Yes & North Atlantic Ocean, Indian Ocean & $\begin{array}{l}\text { Pasternak 1964; } \\
\text { Williams 1995; } \\
\text { López-González \& } \\
\text { Williams } 2011\end{array}$ \\
\hline $\begin{array}{l}\text { Umbellula hemigymna } \\
\text { Pasternak, } 1975\end{array}$ & No & Caribbean Sea & $\begin{array}{l}\text { Pasternak 1975; } \\
\text { Williams } 1995\end{array}$ \\
\hline Umbellula pomona sp. nov. & Yes & $\begin{array}{l}\text { South Atlantic Ocean, Mar del Plata } \\
\text { Submarine Canyon }\end{array}$ & This paper \\
\hline
\end{tabular}

species with sclerites and a round axis, characters also presents in U. pomona sp. nov., which supports this clade from the morphological data. If both clades were to be separated in two genera, 'Umbellula clade I' would retain the generic name Umbellula (since it includes the type species of the genus) and a new genus would have to be proposed for 'Umbellula clade II'. Pending a complete revision of the nominal species assigned to Umbellula, we prefer to be conservative and include our species within Umbellula until a such revision is done and a decision based on molecular and morphological data can be made.

\section{Valid species within Umbellula}

Up to date, there are 43 nominal species within Umbellula (Williams 1995; Cordeiro et al. 2019; this paper). At least nine species were recognized as probably valid by Williams (1995) (U. durissima, U. monocephalus, U. thomsoni, U. hemigymna, U. huxleyi, U. lindahli, U. pellucida, U. spicata and 
U. encrinus). Later, López-González \& Williams (2011) disagreed with some specimens' identifications and shared the vision of Pasternak (1962) that U. carpenteri and U. magniflora Kölliker, 1880 are possibly the same species. On the other hand, Broch (1957) in his revision of the family considered $U$. thomsoni and $U$. leptocaulis Kölliker, 1880 as the same species. In this work, we consider the valid species according to the revision made by Broch (1957) and López-González \& Williams (2011). Clearly, a complete revision of Umbellula spp. is needed, probably using both morphological and molecular data. Table 3 shows the valid species of Umbellula with their known distributions considered in this paper.

\section{On the distribution of Umbellula spp. of the South Atlantic Ocean (SAO)}

Umbellula is a cosmopolitan genus (Table 3). Specimens of this group have been reported from all over the world, from the equator to the poles. Reports of Umbellula in the South Atlantic are limited; according to the papers made by Broch (1958) and Williams (1995), only four species were reported in the SAO: $U$. durissima, $U$. monocephalus, $U$. thomsoni and $U$. lindahli, of which only $U$. thomsoni and $U$. lindahli correspond to the southwestern Atlantic Ocean (SAO), where our specimens are located. The diversity of the group in Antarctic waters is also low, with three species reported (U. durissima, U. lindahli and U. carpenteri) (Kölliker 1880; Broch 1958; López-González \& Williams 2011). As mentioned before, the conditions in the sampled area are strongly influenced by the Malvinas Current and the Brazil-Malvinas Confluence, which may explain the presence of Antarctic species in the SAO deep sea. Given the depths where our specimens came from $(2934 \mathrm{~m}$ and $3282 \mathrm{~m})$, it is possible that this record is (or is near to) the southern limit distribution of the species, since in the confluence area at that depth the North Atlantic Deep waters are present (see Voigt et al. 2013), which run southward from the northern hemisphere and in the confluence area divide the Circumpolar Deep Water vertically in two, staying at a depth of 2000-3000 m. A similar situation has also been proposed in the case of the gastropod Theta lyronuclea (Clarke, 1959), previously reported from the North Atlantic Ocean and recently found in the same station as U. pomona sp. nov. (Sánchez \& Pastorino 2020).

\section{Acknowledgments}

Many thanks are due to the crew of the O/V Puerto Deseado for their assistance. Special thanks to Pablo Penchaszadeh for the support given to Daniel Lauretta and Jessica Risaro during this work and to Luis Piacentini for helping with the molecular data analysis. This manuscript was greatly improved by the comments and suggestions made by the anonymous reviewers.

\section{Funding}

This work was supported by PIP 2017-0643 (CONICET-National Scientific and Technical Research Council), an Idea Wild and PADI (Professional Association of Diving Instructors) grant to Daniel Lauretta; and a PICT (Agencia Nacional de Promoción Científica y Tecnológica) 2013-2504 grant to Pablo Penchaszadeh. Support was provided by the National Scientific and Technical Research Council (Argentina) to Daniel Lauretta.

\section{Compliance with ethical standards}

\section{Conflict of interest}

The authors declare that they have no conflict of interest.

\section{Ethical approval}

All applicable international, national, and/or institutional guidelines for the care and use of animals were followed by the authors.

\section{Sampling and field studies}

All necessary permits for sampling and observational field studies have been obtained by the authors from the competent authorities and are mentioned in the acknowledgements. 


\section{Data availability}

The datasets generated during the current study are available from the corresponding authors on reasonable request.

\section{References}

Acuña F.H. \& Zamponi M.O. 1992. Pennatulacea (Cnidaria: Octocorallia) de la región subantártica: nuevos taxa y registros. Iheringia Série Zoologia 73: 47-53. Available from https://www.biodiversitylibrary.org/page/34350169\#page/585/mode/1 up [accessed 10 Sep. 2020].

Altschul S.F., Gish W., Miller W., Myers E.W. \& Lipman D.J. 1990. Basic local alignment search tool. Journal of Molecular Biology 215: 403-410. https://doi.org/10.1016/S0022-2836(05)80360-2

Bayer F.M., Grasshoff M. \& Verseveldt J. 1983. Illustrated Trilingual Glossary of Morphological and Anatomical Terms Applied to Octocorallia. E.J. Brill/Dr. Backhuys. Leiden. Available from https://repository.si.edu/handle/10088/6237 [accessed 10 Sep. 2020].

Bernal M.C., Cairns S.D., Penchaszadeh P.E. \& Lauretta D. 2018. Errina argentina sp. nov., a new stylasterid (Hydrozoa: Stylasteridae) from Mar del Plata submarine canyon (Southwest Atlantic). Marine Biodiversity 49: 833-839. https://doi.org/10.1007/s12526-018-0861-1

Broch H. 1957. Pennatularians (Umbellula). In: Jerlov N. \& Kullenberg B. (eds) Report of the Swedish Deep-Sea Expedition (1947-1948). Zoology vol. 2 (3): 347-364. Swedish Natural Science Research Council, Stockholm.

Broch H. 1958. Octocorals Part 1. Pennatularians. Discovery Reports 29. National Institute of Oceanography (1959). Cambridge.

Cerino N. \& Lauretta D. 2013. Armadillogorgia albertoi sp. nov.: a new primnoid from Argentinean deep sea. Zootaxa 3741 (3): 369-376. https://doi.org/10.11646/zootaxa.3741.3.5

Cordeiro R., van Ofwegen L. \& Williams G.C. 2019. World list of Octocorallia Umbellula Gray, 1870. Available from http://www.marinespecies.org/aphia.php?p=taxdetails\&id=128499 [accessed 1 Jul. 2019].

Del Río Iglesias J.L., Acosta Yepes J., Cristobo Rodríguez J., Martínez Portela J., Parra Descalzo S., Tel E., Viñas Diéguez L., Muñoz Recio A., Vilela Pérez R., Elvira Jiménez E., Patrocinio Ibarrola T., Ríos López P., Almón Pazos B., Blanco Pérez R., Murillo Pérez J., Polonio Povedano V., Fernández Feijoó J., Cabanas J.M., Gago Piñeiro J.M., González-Nuevo González G., Cabrero Rodríguez A., Besada Montenegro M.V., Schultze Prado F., Franco Hernández A., Bargiela Barros J. \& García Blanco X. 2012. Study of the Vulnerable Marine Ecosystems in International Waters from the Southoccidental Atlantic. Madrid, Spain.

Dolan E. 2008. Phylogenetics, Systematics and Biogeography of Deep-Sea Pennatulacea (Anthozoa: Octocorallia). PhD thesis, University of Southampton, Faculty of Engineering, Science and Mathematics.

Dolan E., Tyler P.A., Yesson C. \& Rogers A.D. 2013. Phylogeny and systematics of deep-sea sea pens (Anthozoa: Octocorallia: Pennatulacea). Molecular Phylogenetics and Evolution 69: 610-618. https://doi.org/10.1016/j.ympev.2013.07.018

Farias N.E., Ocampo E.H. \& Luppi T.A. 2015. On the presence of the deep-sea blind lobster Stereomastis suhmi (Decapoda: Polychelidae) in Southwestern Atlantic waters and its circum-Antarctic distribution. New Zealand Journal of Zoology 42: 119-125. https://doi.org/10.1080/03014223.2015.1013041

France S.C. \& Hoover L.L. 2002. DNA sequences of the mitochondrial COI gene have low levels of divergence among deep-sea octocorals (Cnidaria: Anthozoa). Hydrobiologia 471: 149-155.

https://doi.org/10.1023/A:1016517724749 
García-Cárdenas F.J., Drewery J. \& López-González P.J. 2019. Resurrection of the sea pen genus Ptilella Gray, 1870 and description of Ptilella grayi n. sp. from the NE Atlantic (Octocorallia: Pennatulacea). Scientia Marina 83 (3): 261-276. https://doi.org/10.3989/scimar.04845.26A

Grasshoff M. 1972. Eine Seefeder mit einem einzigen Polypen: Umbellula thieli n. sp. Die von F.S. 'Meteor'1967-1970 im östlichen Nordatlantik gedredschten Pennatularia (Cnidaria: Anthozoa). Meteor Forschungsergebnisse. Reihe D. Biologie 12: 1-11.

Guindon S., Dufayard J.F., Lefort V., Anisimova M., Hordijk W. \& Gascuel O. 2010. New algorithms and methods to estimate maximum-likelihood phylogenies: assessing the performance of PhyML 3.0. Systematic Biology 59: 307-321. https://doi.org/10.1093/sysbio/syq010

Kölliker R.A. von 1874. Die Pennatulide Umbellula und zwei neue Typen der Alcyonarien. Festschrift zur Feier Ihres Fünfzigjährigen Bestehens, 1899: 1-23. Herausgegeben von der PhysikalischMedizinischen Gesellschaft zu Würzburg.

Kölliker R.A. von 1880. Report on the PENNATULIDA dredged by H.M.S. Challenger during the years 1873-1876. Report on the scientific results of the voyage of H.M.S. Challenger during the years 1873-1876. Zoology 1 (2): 1-41.

Kükenthal W. 1902. Diagnosen neuer Alcyonarien aus der Ausbeute der Deutschen Tiefsee-Expedition. Zoologischer Anzeiger 25: 299-303.

Kükenthal W. 1911. Pennatulacea. In: Kükenthal, W. \& Broch H. Wissenschaftliche Ergebnisse der Deutschen Tiefsee-Expedition auf dem Dampfer "Valdivia" 1898-1899 13 (1, 2): 113-576. Available from https://doi.org/10.5962/bhl.title.2171 [accessed 2 Oct. 2020].

Kükenthal W. 1915. Pennatularia. Das Tierreich 43: 1-132.

Kushida Y. \& Reimer J.D. 2019. Molecular phylogeny and diversity of sea pens (Cnidaria: Octocorallia: Pennatulacea) with a focus on shallow water species of the northwestern Pacific Ocean. Molecular Phylogenetics and Evolution 131: 233-244. https://doi.org/10.1016/j.ympev.2018.10.032

Lanfear R., Frandsen P.B., Wright A.M., Senfeld T. \& Calcott B. 2016. PartitionFinder 2: new methods for selecting partitioned models of evolution for molecular and morphological phylogenetic analyses. Molecular Biology and Evolution 34 (4): 772-773. https://doi.org/10.1093/molbev/msw260

Lauretta D. \& Penchaszadeh P. 2017. Gigantic oocytes in the deep sea black coral Dendrobathypathes grandis (Antipatharia) from the Mar del Plata submarine canyon area (southwestern Atlantic). Deep Sea Research Part I: Oceanographic Research Papers 128: 109-114.

https://doi.org/10.1016/j.dsr.2017.08.011

Linnaeus C. 1758. Systema Naturae, sive regna tria naturae, secundum classes, ordines, genera, species, cum characteribus, differentiis, synonymis, locis. Ed. 10 th. Vol. I. Animalia. Laurentii Salvii. Stockholm [Holmiae]. https://doi.org/10.5962/bhl.title.542

López-González P.J. \& Williams G.C. 2011. A new deep-sea pennatulacean (Anthozoa: Octocorallia: Chunellidae) from the Porcupine Abyssal Plain (NE Atlantic). Helgoland Marine Research 65: 309318. https://doi.org/10.1007/s10152-010-0224-1

Maggioni T., Taverna A. \& Tatián M. 2016. Redescription of the deep-sea colonial ascidian Synoicum molle (Herdman, 1886): first record since its original finding during the Challenger Expedition. Zoosystematics and Evolution 92 (2): 181-185. https://doi.org/10.3897/zse.92.9521

Martinez M.I. \& Penchaszadeh P.E. 2017. A new species of brooding Psolidae (Echinodermata: Holothuroidea) from deep-sea off Argentina, Southwestern Atlantic Ocean. Deep-Sea Research Part II: Topical Studies in Oceanography 146: 13-17. https://doi.org/10.1016/j.dsr2.2017.05.007 
Martinez M.I., Solís-Marín F.A. \& Penchaszadeh P.E. 2014. Benthodytes violeta, a new species of a deep-sea holothuroid (Elasipodida: Psychropotidae) from Mar del Plata Canyon (south-western Atlantic Ocean). Zootaxa 3760 (1): 89-95. https://doi.org/10.11646/zootaxa.3760.1.6

Martinez M.I., Solís-Marín F.A. \& Penchaszadeh P.E. 2019. First report of Paelopatides (Synallactida, Synallactidae) for SW Atlantic, with description of new species from the deep-sea off Argentina. Zoologischer Anzeiger 278: 21-27. https://doi.org/10.1016/j.jcz.2018.10.010

McFadden C.S., Tullis I.D., Hutchinson M.B., Winner K. \& Sohm J.A. 2004. Variation in coding (NADH dehydrogenase subunits 2, 3 and 6) and non-coding intergenic spacer regions of the mitochondrial genome in Octocorallia (Cnidaria: Anthozoa). Marine Biotechnology 6: 516-526.

https://doi.org/10.1007/s10126-002-0102-1

McFadden C.S., France S.C., Sánchez J.A. \& Aldersaade P. 2006. A molecular phylogenetic analysis of the Octocorallia (Cnidaria: Anthozoa) based on mitochondrial protein-coding sequences. Molecular Phylogenetics and Evolution 41: 513-527. https://doi.org/10.1016/j.ympev.2006.06.010

Miller M.A., Pfeiffer W. \& Schwartz T. 2010. Creating the CIPRES Science Gateway for inference of large phylogenetic trees. Proceedings of the Gateway Computing Environments Workshop (CGE). 14 Nov. 2010, New Orleans, LA: 1-8.

Miller S.A., Dikes D.D. \& Polesky H.F. 1988. A simple salting out procedure for extracting DNA for human nucleated cells. Nucleic Acids Research 16 (3): 1215. https://doi.org/10.1093/nar/16.3.1215

Pasternak F.A. 1962. Pennatularia of the genus Umbellula Cuvier (Coelenterata, Octocorallia) from Antarctic and Subantarctic Waters. Biological Reports of the Soviet Antarctic Expedition (1955-1958) 1: 107-130 [In Russian.]

Pasternak F.A. 1964. The deep-sea pennatularians and antipatharians obtained by R/S "Vitjaz" in the Indian Ocean and the resemblance between the fauna of the pennatularians of the Indian Ocean and the Pacific. Trudy Instituta okeanologii, Akademiya nauk SSSR 69: 183-215 [In Russian.]

Pasternak F.A. 1975. Deep-sea pennatularians genus Umbellula from the Caribbean Sea and Puerto Rican Trench. Vol. 1000: Scientific studies Caribbean Sea, Gulf of Mexico and adjacent waters. Transactions of the P.P. Shirsov Institute of Oceanology 100: 160-173. [In Russian, with English summary.]

Pastorino G. 2016. First report of the family Laubierinidae Warén \& Bouchet, 1990 (Gastropoda: Tonnoidea) in the southwestern Atlantic. Molluscan Research 36: 108-111. https://doi.org/10.1080/13235818.2015.1128582

Pastorino G. 2019. A new deep water gastropod of the genus Parabuccinum (Neogastropoda: Buccinulidae) from southwestern Atlantic waters with new data on the distribution of all species. Marine Biodiversity 49: 913-922. https://doi.org/10.1007/s12526-018-0876-7

Pastorino G. \& Sánchez N. 2016. Southwestern Atlantic species of conoidean gastropods of the genus Aforia Dall, 1889. Zootaxa 4109: 1175-5326. https://doi.org/10.11646/zootaxa.4109.4.4

Pereira E. \& Doti B. 2017. Edotia abyssalis n. sp. from the Southwest Atlantic Ocean, first record of the genus (Isopoda, Valvifera, Idoteidae) in the deep sea. Zoologischer Anzeiger 268: 19-31.

https://doi.org/10.1016/j.jcz.2017.04.007

Pérez C.D. \& Zamponi M.O. 2004. New records of octocorals (Cnidaria, Anthozoa) from the south western Atlantic Ocean, with zoogeographic considerations. Zootaxa 630: 1-12.

https://doi.org/10.11646/zootaxa.630.1.1

Piola R.A. \& Matano R.P. 2001. Brazil and Falklands (Malvinas) currents. Encyclopedia of Ocean Sciences: 340-349. https://doi.org/10.1006/rwos.2001.0358 
Rambaut A., Drummond A.J., Xie D., Baele G. \& Suchard M.A. 2018. Posterior summarisation in Bayesian phylogenetics using Tracer 1.7. Systematic Biology 67 (5): 901-904.

https://doi.org/10.1093/sysbio/syy032

Ronquist F., Teslenko M., Van Der Mark P., Ayres D.L., Darling A., Höhna S., Larget B., Liu L., Suchard M.A. \& Huelsenbeck J.P. 2012. MrBayes 3.2: efficient Bayesian phylogenetic inference and model choice across a large model space. Systematic Biology 61: 539-542.

https://doi.org/10.1093/sysbio/sys029

Sánchez J.A., McFadden C.S., France S.C. \& Lasker H.R. 2003. Molecular phylogenetic analyses of shallow-water Caribbean octocorals. Marine Biology 142: 975-987.

https://doi.org/10.1007/s00227-003-1018-7

Sánchez N. \& Pastorino G. 2020. The North Atlantic conoidean gastropod Theta lyronuclea (Raphitomidae) in deep-waters of the Southwestern Atlantic. Malacologia 63 (1): 33-40.

https://doi.org/10.4002/040.063.0104

Signorelli J. \& Pastorino G. 2015. A new species of Laubiericoncha (Bivalvia: Vesicomyidae) from deep waters off Argentina. Malacologia 58: 349-360. https://doi.org/10.4002/040.058.0213

Thomson J.A. \& Henderson W.D. 1906. An Account of the Alcyonarians Collected by the Royal Indian Marine Survey Ship 'Investigator' in the Indian Ocean. 1. The Alcyonarians of the Deep Sea. Trustees of the Indian Museum, Calcuta.

Tiefenbacher L. 2001. Umbellula monocephalus Pasternak, 1964, eine seltene Pennatularia aus dem südlichen Westeuropäischen Becken (Anthozoa, Octocorallia, Pennatularia). Spixiana 24 (1): 1-4.

Available from https://www.biodiversitylibrary.org/page/28196307\#page/7/mode/1up [accessed 11 Sep. 2020].

Voigt I., Henrich R., Preua B.M., Piola A.R., Hanebuth T.J.J., Schwenk T. \& Chiessi C.M. 2013. A submarine canyon as a climate archive - Interaction of the Antarctic Intermediate Water with the Mar del Plata Canyon (Southest Atlantic). Marine Geology 341: 46-57.

https://doi.org/10.1016/j.margeo.2013.05.002

Williams G.C. 1990. The Pennatulacea of southern Africa (Coelenterata, Anthozoa). Annals of the South African Museum 99: 31-119. Available from https://www.biodiversitylibrary.org/page/40684114\#page/69/mode/1up [accessed 11 Sep. 2020].

Williams G.C. 1992. Biogeography of the octocorallian coelenterate fauna of southern Africa. Biological Journal of the Linnean Society 46: 351-401. https://doi.org/10.1111/j.1095-8312.1992.tb00869.x

Williams G.C. 1995. Living genera of sea pens (Coelenterata: Octocorallia: Pennatulacea): illustrated key and synopses. Zoological Journal of the Linnean Society 113: 93-140.

https://doi.org/10.1111/j.1096-3642.1995.tb00929.x

Williams G.C. 2011. The global diversity of sea pens (Cnidaria: Octocorallia: Pennatulacea). PLoS ONE 6 (7): e22747. https://doi.org/10.1371/journal.pone.0022747

Williams G.C. 2015. A new genus and species of pennatulacean octocoral from equatorial West Africa (Cnidaria, Anthozoa, Virgulariidae). ZooKeys 546: 39-50. https://doi.org/10.3897/zookeys.546.6344

Williams G.C. \& Alderslade P. 2011. Three new species of pennatulacean octocorals with the ability to attach to rocky substrata (Cnidaria: Anthozoa: Pennatulacea). Zootaxa 3001: 33-48.

https://doi.org/10.11646/zootaxa.3001.1.2

Zamponi M.O. \& Pérez C.D. 1995. Revision of the genus Renilla Lamark, 1816 (Octocorallia, Pennatulacea), with descriptions of two new species from the Sub-Antarctic region. Miscel-lània Zoològica 18: 21-32. 
Manuscript received: 29 August 2019

Manuscript accepted: 27 July 2020

Published on: 13 October 2020

Topic editor: Rudy Jocqué

Desk editor: Pepe Fernández

Printed versions of all papers are also deposited in the libraries of the institutes that are members of the EJT consortium: Muséum national d'histoire naturelle, Paris, France; Meise Botanic Garden, Belgium; Royal Museum for Central Africa, Tervuren, Belgium; Royal Belgian Institute of Natural Sciences, Brussels, Belgium; Natural History Museum of Denmark, Copenhagen, Denmark; Naturalis Biodiversity Center, Leiden, the Netherlands; Museo Nacional de Ciencias Naturales-CSIC, Madrid, Spain; Real Jardín Botánico de Madrid CSIC, Spain; Zoological Research Museum Alexander Koenig, Bonn, Germany; National Museum, Prague, Czech Republic.

\section{Supplementary material}

Supplementary file 1. Primer's sequences and PCR conditions used to amplify partial regions of the mitochondrial mtMutS and ND2 genes. https://doi.org/ejt.2020.720.1121.2933 